\title{
Immune Dysfunction in Autism: A Pathway to Treatment
}

\author{
Milo Careaga, ${ }^{* \dagger}$ Judy Van de Water, ${ }^{\ddagger}$ and Paul Ashwood ${ }^{\dagger}$ \\ $*$ Department of Medical Microbiology and Immunology, ${ }^{\dagger}$ M.I.N.D. Institute, and ${ }^{\ddagger}$ Division of Rheumatology, Allergy and \\ Clinical Immunology, University of California at Davis, Sacramento, California 95817
}

\begin{abstract}
Summary: Autism is a complex and clinically heterogeneous disorder with a spectrum of symptoms. Clinicians, schools, and service agencies worldwide have reported a dramatic increase in the number of children identified with autism. Despite expanding research, the etiology and underlying biological processes of autism remain poorly understood, and the relative contribution from genetic, epigenetic, and environmental factors remains unclear. Although autism affects primarily brain function (especially affect, social functioning, and cognition), it is unknown to what extent other organs and systems are disrupted. Published findings have identified widespread changes in the immune systems of children with autism, at both systemic and cellular levels. Brain specimens from autism subjects
\end{abstract}

exhibit signs of active, ongoing inflammation, as well as alterations in gene pathways associated with immune signaling and immune function. Moreover, many genetic studies have indicated a link between autism and genes that are relevant to both the nervous system and the immune system. Alterations in these pathways can affect function in both systems. Together, these reports suggest that autism may in fact be a systemic disorder with connections to abnormal immune responses. Such immune system dysfunction may represent novel targets for treatment. A better understanding of the involvement of the immune response in autism, and of how early brain development is altered, may have important therapeutic implications. Key words: Autism, immune system, autoimmunity, signaling pathways.

\section{HISTORICAL LINKS OF AUTOIMMUNITY AND AUTISM}

Immunological dysfunction has been a recognized feature in autism spectrum disorders (ASD) for several decades, but controversy remains in terms of both its existence and its etiologic role. As early as 1971, a relationship between ASD and immune dysfunction was proposed by Money et al., ${ }^{1}$ who reported a familial link of polyendocrine autoimmune disorder with ASD. In more recent years, several epidemiologic studies have sought to determine if there is more than an anecdotal familial link between ASD and autoimmunity or immune dysfunction. Since 1999, at least eight studies have been conducted to address this issue. In seven of these studies, an association between familial autoimmunity and ASD was determined. In all but two of the studies, ${ }^{2,3}$ however, the number of subjects was relatively small, and interpretation is compounded by the fairly low rate at which autoimmune diseases occur in the general population ${ }^{4}$ (Table 1).

Address correspondence and reprint requests to: Paul Ashwood, Ph.D., M.I.N.D. Institute, University of California at Davis, 2805 50th Street, Sacramento, CA 95817. E-mail: pashwood@ucdavis.edu.
The second major issue with these studies is the manner in which autoimmunity in families was determined. To date, the majority of studies have used self-reporting questionnaires, which are prone to inaccuracy and potential over-reporting. However, from a large populationbased study (nearly 700,000 participants) in which both the ASD diagnosis and family history of autoimmune disease were obtained from medical records and not from surveys, Atladóttir et al. ${ }^{2}$ found that some autoimmune disease were more common in parents of children with ASD. That study indicated increased rates of rheumatoid arthritis and celiac disease in mothers of children with ASD, and a higher rate of the autoimmune condition type 1 diabetes in both mothers and fathers. Similarly, in another large population-based case-control study, Croen et al. $^{3}$ found an increase in the autoimmune conditions of psoriasis and type 1 diabetes, as well as immune-mediated disorders such as asthma and allergies in mothers of children with ASD. That study was based on data recorded by physicians during the 4 -year period surrounding pregnancy. Both of these large population-based studies support the theory that autoimmune responses and immune dysfunction at or around the time of pregnancy may be related to a later diagnosis of ASD in the offspring. 
Table 1. Epidemiological Studies of Autoimmunity and Immune dysfunction in Families of Children with ASD

\begin{tabular}{|c|c|c|c|c|}
\hline References & $\begin{array}{l}\text { Study } \\
\text { population, no. }\end{array}$ & Reporting & $\begin{array}{l}\text { Association } \\
\text { with ASD? }\end{array}$ & $\begin{array}{c}\text { Autoimmune diseases and immune } \\
\text { dysfunction }\end{array}$ \\
\hline Comi et al. ${ }^{5}$ (1999) & 107 & Self-report & Yes & $\begin{array}{l}\text { Rheumatoid arthritis (mat); } \\
\text { general autoimmunity (mat, pat) }\end{array}$ \\
\hline Sweeten et al. ${ }^{6}$ (2003) & 303 & Self-report & Yes & $\begin{array}{l}\text { Hypothyroidism and Hashimoto's } \\
\text { thyroiditis (mat, pat); rheumatic } \\
\text { fever (mat, pat) }\end{array}$ \\
\hline Micali et al. ${ }^{7}$ (2004) & 140 & Self-report & No & - \\
\hline Croen et al. ${ }^{3}(2005)$ & 2,520 & Medical records & Yes & $\begin{array}{l}\text { Psoriasis (mat), asthma and } \\
\text { allergies }\end{array}$ \\
\hline Molloy et al. ${ }^{8}$ (2006) & 308 & Self-report & Yes & $\begin{array}{l}\text { Autoimmune thyroid disease (mat, } \\
\text { pat)* }\end{array}$ \\
\hline Mouridsen et al. ${ }^{9}$ (2007) & 441 & Medical records & Yes & $\begin{array}{l}\text { Ulcerative colitis (mat); type } 1 \\
\text { diabetes }\end{array}$ \\
\hline Valicenti-McDermott et al. ${ }^{10}$ (2008) & 100 & Self-report & Yes & $\begin{array}{l}\text { Rheumatoid arthritis (mat) }{ }^{\dagger} \text {; celiac } \\
\text { disease (mat) }\end{array}$ \\
\hline Atladóttir et al. ${ }^{2}$ (2009) & 689,196 & Medical records & Yes & $\begin{array}{l}\text { Rheumatoid arthritis (mat); celiac } \\
\text { disease (mat); type } 1 \text { diabetes } \\
\text { (mat, pat) }\end{array}$ \\
\hline
\end{tabular}

ASD = autism spectrum disorder; mat = maternal (autoimmunity link in mothers); pat = paternal (autoimmunity link in fathers).

*Autoimmune thyroid disease was found to be associated with the families of children with regressive ASD. ${ }^{\dagger}$ Rheumatoid arthritis and celiac disease in this study were associated with language regression.

Nonetheless, given the diversity of autoimmune disorders associated with ASD in these two studies, ${ }^{2,3}$ no clear link between specific autoimmune diseases and ASD is readily apparent. The data suggest that global immune dysfunction in mothers during pregnancy, rather than specific diseases, may be associated with increased risk for ASD. Furthermore, although in most studies the increased rate of autoimmunity was limited to the mothers, others have found this link present in the fathers as well, suggesting that not only the timing of immune responses but also underlying heritable immunogenetic factors could be contributing to both the autoimmunity and the ASD.

It is also possible that immune dysfunction is not linked with all forms of ASD, but is confined to a specific subphenotype of ASD or is associated with specific behavioral features. Molloy et al. ${ }^{8}$ reported more frequent familial autoimmune thyroid disease in children diagnosed with a regressive form of ASD, compared with children diagnosed with an early-onset form. Identifying whether there are specific endophenotypes of ASD that are linked with autoimmunity and immune dysfunction will help to elucidate the mechanism involved, as well as potentially identifying those individuals who could benefit from therapeutic immune interventions.

\section{MATERNAL ANTIBODIES}

The finding of an increased history of autoimmune disorders in families of children with ASD is provocative, but does not identify the specific mechanisms that play a role in the pathogenesis of the disorder. The maternal transfer of autoantibodies from the mother to child during pregnancy is well documented, and is associated with a number of factors that can affect both pregnancy and neonatal outcome. ${ }^{11}$ The presence of autoantibodies directed against critical neuronal components of fetal brain extracts in a subset of mothers of ASD children provides supporting evidence that one potential mechanism linking maternal immune components with ASD involves the transfer of autoantibodies from mother to the developing fetus during pregnancy $^{15,16,17,20}$ (Table 2).

One possibility is that anti-fetal brain autoantibodies, found in approximately $12 \%$ of mothers of children with ASD, bind to their neuronal targets during development, thereby interfering with or altering neurodevelopment. The phenomenon of maternal autoantibodies affecting the health of offspring has been reported in mothers with systemic lupus erythematosus whose children are born with congenital heart block. ${ }^{21-24}$ Furthermore, neurotoxic autoantibodies from patients with systemic lupus erythematosus transferred into pregnant mice result in abnormal brain development in the offspring. ${ }^{25}$

Although it is hard to reproduce exactly the core features of autism in animal models, certain behaviors associated with ASD can be replicated, such as repetitive behaviors, learning, and hyperactivity. ${ }^{26}$ In one model, the transference of IgG isolated from mothers with children with ASD into rhesus macaque monkeys during midgestation resulted in distinct behavioral changes in the offspring, which were not observed in monkeys that received IgG from mothers of typically developing children or monkeys that were saline treated. ${ }^{18}$ Similar experiments in mice show that behavioral changes are pro- 
Table 2. Autoantibodies Directed to Brain Proteins in Mothers of Children with ASD

\begin{tabular}{|c|c|c|}
\hline References & Target of maternal antibodies & Tissue source \\
\hline Warren et al. ${ }^{13}$ (1990) & Lymphocytes from children with ASD & Peripheral blood from children \\
\hline Dalton et al. ${ }^{14}$ (2003) & $\begin{array}{l}\text { Murine cerebellar Purkinje cells and } \\
\text { brainstem neurons }\end{array}$ & $\begin{array}{l}\text { Mouse* postnatal day } 1 \text { and adult } \\
\text { brain }\end{array}$ \\
\hline Zimmerman et al. $^{15}$ (2007) & Unknown 30 and $>250 \mathrm{kDa}$ proteins & $\begin{array}{l}\text { Fetal, postnatal, and adult rat brain } \\
\text { extracts }\end{array}$ \\
\hline Croen et al. ${ }^{12}(2008)$ & Unknown 37,39 , and $73 \mathrm{kDa}$ protein & maternal blood; fetal brain extract \\
\hline Braunschweig et al. $^{16}$ (2008) & $\begin{array}{l}\text { Unknown } 37 \mathrm{kDa} \text { and } 73 \mathrm{kDa} \text { protein } \\
\text { (no reactivity to adult brain) }\end{array}$ & Human fetal and adult brain extract \\
\hline Singer et al. ${ }^{17}$ (2008) & $\begin{array}{l}\text { Unknown } 36 \text { and } 39 \mathrm{kDa} \text { protein; } \\
\text { unknown } 73 \mathrm{kDa} \text { to rat embryo }\end{array}$ & $\begin{array}{l}\text { Adult and fetal rat and human brain } \\
\text { extracts }\end{array}$ \\
\hline Martin et al. ${ }^{18}(2008)$ & Unknown 60 and $73 \mathrm{kDa}$ protein & Fetal brain extract, Rhesus macaques* \\
\hline Singer et al. ${ }^{19}$ (2009) & Microglia cells & embryonic mouse cortex, Mice* \\
\hline
\end{tabular}

*Transfer of human maternal autoantibodies to pregnant animals.

duced after antibodies from mothers of children with ASD (but not antibodies from typically developing control subjects) are injected into mice during midgestation. ${ }^{18,19}$

Whether these behavioral changes are directly related to ASD or are themselves distinct phenomena is not clear. Nonetheless, these models suggest that antibodies isolated from mothers with ASD children may alter the course of early neurodevelopment, leading to changes in behavior in the offspring. Future studies will need to better characterize the behavioral changes evoked by these antibodies and their relevance to core features or symptoms of ASD, as well as the potential cellular targets of these antibodies. Although the frequency at which potential autoantibodies are present in mothers who have children with ASD is low, the significance of carrying these antibodies may be substantial ${ }^{16}$ and presents an exciting avenue for screening and therapy.

\section{AUTOIMMUNITY AND IMMUNE DYSFUNCTION IN INDIVIDUALS WITH ASD}

Observations of autoimmunity are not limited to families of the children with ASD. Numerous studies point to the presence of immune dysfunction in some children with ASD, much of which is consistent with autoimmunity (see review by Enstrom et al. ${ }^{27}$ ).

Autoimmune diseases appear to result from a complex interaction of environmental and genetic factors. Numerous genes are thought to be associated with an increased risk of developing certain autoimmune diseases. The human leukocyte antigen (HLA) genes are among the strongest predictors of risk for autoimmune conditions (see review by Fernando et al. ${ }^{28}$ ). Different HLA haplotypes are also associated with neurodevelopmental disorders, such as schizophrenia and ASD (Table 3).

In ASD, early findings by Stubbs et al. ${ }^{30}$ suggested that mothers of children with ASD share HLA haplo- types with their children more often than do typically developing mother-child pairs. Further studies found that several HLA haplotypes, in particular HLA-DR4, occur more often in children with ASD than in the general population. ${ }^{32,33,36,37}$

The HLA genes are located within a large genomic region referred to as the major histocompatibility complex (MHC). This region contains numerous other genes, including the complement protein $\mathrm{C} 4$ gene $(C 4 A$; alias $C 4 B$ ), which is important for innate immunity. Allelic deficiencies in the this gene, as well as its protein product, have been reported in ASD. ${ }^{40-42}$ In ASD children from Sardinia, Guerini et al. ${ }^{38}$ found no apparent HLA linkage, but several microsatellite linkages within the MHC were associated with ASD. These data suggest that genetic abnormalities in the MHC are not solely confined to HLA genes themselves, but also include genes in near proximity. In addition, a number of other immunerelated genes have been implicated in ASD, including macrophage migration inhibitory factor $(M I F),{ }^{43}$ MET encoding tyrosine kinase, ${ }^{44}$ the serine and threonine kinase $\mathrm{C}$ gene $P R K C B$ (alias $P R K C B 1),{ }^{45}$ protein phosphatase and tensin homolog $(P T E N),{ }^{46}$ and the reelin gene $\left(\right.$ RELN). ${ }^{47-49}$

It is not known whether immune activation plays an initiating or ongoing role in the pathology of ASD. Immune activation leading to inflammation can have serious detrimental effects and could lead to destruction of tissues. Increased immune activation is associated with a number of neurodegenerative disorders and is speculated to play a role in psychiatric disorders such as schizophrenia, obsessive compulsive disorder, depression, bipolar disorder, and Gilles de La Tourette disorder, as well as ASD. Elevated levels of inflammatory cytokines in the CNS could reflect an inflammatory process that might contribute to abnormal neurodevelopment as seen in ASD.

Increased levels of proinflammatory cytokines such as IL-6, TNF $\alpha$, and MCP-1 in brain specimens and CSF 
Table 3. Genetic Studies of Human Leukocyte Antigen (HLA) Haplotypes in Individuals with ASD

\begin{tabular}{|c|c|c|c|c|}
\hline References & $\begin{array}{l}\text { Association } \\
\text { with ASD? }\end{array}$ & HLA & Study population, no. & Region \\
\hline Stubbs et al. ${ }^{29}$ (1980) & No & Not available & 20 families; 757 controls & Not specified \\
\hline Stubbs et al. ${ }^{30}(1985)$ & Yes & Shared HLA* & $\begin{array}{l}52 \text { families; } 83 \text { families } \\
\text { (historical) }\end{array}$ & $\begin{array}{l}\text { Oregon and southern California; } \\
\text { United Kingdom }\end{array}$ \\
\hline Spence et al. ${ }^{31}$ (1985) & No & Not available & 27 families & Not specified \\
\hline Warren et al. ${ }^{32}$ (1992) & Yes & B44-SC30-DR4 & 21 families; 62 controls & Utah \\
\hline Daniels et al. ${ }^{33}$ (1995) & Yes & B44-SC30-DR4 & 44 families; 126 controls $^{\dagger}$ & Utah \\
\hline Warren et al. ${ }^{34}(1996)$ & Yes & HLA-DRB 1 & 45 subjects; 79 controls & Not specified \\
\hline Rogers et al. ${ }^{35}$ (1999) & No & Not available & 90 families & Not specified \\
\hline Torres et al. ${ }^{36}(2002)$ & Yes & $\begin{array}{l}\text { HLA-DR4; HLA- } \\
\text { DR13 (protective) }\end{array}$ & 103 families & Oregon and Utah \\
\hline Lee et al. ${ }^{37}$ (2006) & Yes and $\mathrm{No}^{\ddagger}$ & HLA-DR4 & $\begin{array}{l}16 \text { and } 33 \text { families; } 475 \\
\text { normal controls }\end{array}$ & Tennessee; United States \\
\hline Guerini et al. ${ }^{38}$ (2009) & $\mathrm{No}^{\S}$ & Microsatellite regions & 37 families & Sardinia \\
\hline Johnson et al. ${ }^{39}$ (2009) & Yes & HLA-DR4 ${ }^{\|}$ & 31 families & New Jersey \\
\hline
\end{tabular}

*Stubbs et al. ${ }^{30}$ found that mothers of children with ASD had similar HLA types more often than did typically developing mother-child pairs. Daniels et al. ${ }^{33}$ added 23 new families to the 1992 cohort of Warren et al., and added 64 new control subjects.

${ }^{\ddagger}$ Lee et al. ${ }^{37}$ Differences were found between the geographical defined families and controls, but not between the geographical diverse families and controls.

${ }^{\S}$ Guerini et al ${ }^{38}$ did not find an HLA linkage, but did find linkages to microsatellite regions in proximity to previously reported HLA linkages.

$\|_{\text {Johnson et al. }}{ }^{39}$ found that HLA DR4 was associated with mothers of children with ASD.

obtained from young and old individuals with ASD (age range 5-44 years) suggest that an active neuroinflammatory process is ongoing in ASD. ${ }^{50}$ Studies that assess cytokine levels in the periphery have often shown similar increases in proinflammatory cytokines, ${ }^{51-55}$ as well as decreases in anti-inflammatory cytokines such as IL- $10^{24,52}$ and TGF $\beta .{ }^{56}$ However, not all studies have shown a consistent pattern of specific cytokines, and data so far collected suggest a complex pattern of immune activation that varies among different subgroups of individuals with ASD.

Several studies have focused on immunological responses to dietary proteins, such as gluten and casein. Jyonouchi et al. ${ }^{57}$ found that peripheral blood mononuclear cells from children with ASD responded to gliadin, cow's milk protein, and soy by producing higher levels of inflammatory cytokines, compared with peripheral blood mononuclear cells from typically developing children. However, children in this study were selected on the basis of having previously seen behavior improvements on a restricted diet and may translate to a specific subgroup of ASD who have gastrointestinal (GI) symptoms. Studies looking at mucosal immune responses in children with ASD who have GI symptoms have shown increased infiltration of T-cell, monocyte, and eosinophil in the gut mucosa, prominent mucosal T-cell activation with increased TNF $\alpha$ but lower IL-10 production, and increased numbers of paneth cells, compared with noninflamed control subjects or compared with children with celiac disease or inflammatory bowel diseases. ${ }^{51,52,58,59}$

Uncertainty remains as to how prevalent GI abnormalities in ASD are and how GI symptoms may relate to core features of ASD or associated behavioral symptoms. A few small studies suggest that GI symptoms in ASD may be related to symptoms of aggression and hyperactivity, and that in some cases individuals with ASD may benefit from immune therapies targeting GI issues (to resolve activated mucosal immune responses). According to one recent report, a case of celiac disease was mistaken for ASD; upon removal of gluten from the patient's diet, and implementation of a modified diet, behaviors improved. ${ }^{60}$ Such studies suggest that an abnormal immune response, in this case to a dietary protein, could contribute to behavioral abnormalities associated with ASD.

The presence of antibodies directed against adult brain or CNS tissue but not fetal brain tissue has been repeatedly reported in children with ASD (see reviews by Enstrom et al. ${ }^{27}$ and Wills et al. ${ }^{61}$ ). These antibodies have varied targets, including neurotransmitter receptors, neuronal proteins, and nuclear material (Table 4). It is not clear, however, whether these autoantibodies have direct pathogenic relevance or are instead secondary to previous cellular damage or inflammatory reactions. Although some investigators have analyzed whether antibodies are directed at specific targets, such as myelin basic protein or glial fibrillary acidic protein, to date no clear associations between ASD and specific antibodies have been replicated across studies. This lack of specificity may suggest that the antibodies are generated as a consequence of some previous indiscriminate damage that involves different brain or CNS targets, leading to the generation of a diverse array of antibody specificities, as seen in ASD. Alternatively, the presence of these 
Table 4. The Presence of Antibodies Directed Against Adult Brain or CNS Tissue in Children with ASD

Study investigators (year)
Antibody Directed Toward

Positive or Negative?

Todd et al. ${ }^{62}$ (1985)

Singh et al. ${ }^{63}$ (1993)

Singh et al. ${ }^{64}$ (1997)

Singh et al. ${ }^{65}$ (1998)

Evers et al. ${ }^{66}$ (2002)

Vodjani et al. ${ }^{67}$ (2004)

Singh et al. ${ }^{68}$ (2004)

Singh et al. ${ }^{69}$ (2004)

Silva et al. ${ }^{20}$ (2004)

Connolly et al. ${ }^{70}$ (2006)

Singer et al. ${ }^{71}$ (2006)

Libbey et al. ${ }^{72}$ (2008)

Kirkman et al. ${ }^{73}$ (2008)

Wills et al. ${ }^{74}$ (2009)
Serotonin receptor

Myelin basic protein (MBP)

Neuron-axon acidic protein (NAFP); glial fibrillary acidic protein (GFAP)

Myelin basic protein (MBP); neuron-axon filament

Heat shock protein 90 (HSP90)

Gliadin; cerebellar peptides; heat shock protein 60 (HSP60)

Caudate nucleus; cerebral cortex; cerebellum

Nucleus and laminin

Unknown $\sim 20 \mathrm{kDa}$ protein

Brain-derived neurotrophic factor (BDNF); endothelial cells (EC); myelin basic protein

Unknown 73 and $100 \mathrm{kDa}$ proteins

Myelin basic protein

Glial fibrillary acidic protein (GFAP)

Unknown $52 \mathrm{kDa}$ protein
Positive

Positive

Positive

Positive

Positive

Positive

Positive

Negative

Positive*

Positive

Positive

Negative

Negative

Positive

*Silva et al. ${ }^{69}$ found a positive finding for a $\sim 20 \mathrm{kDa}$ protein, but determined it not to be MBP.

autoantibodies could reveal a group of ASD subjects who are more prone to immune dysfunction. Notably, antibodies directed at gut epithelium have also been described in ASD children; ${ }^{75}$ however, no link between gut and brain antibodies has yet been established.

\section{DEFICITS IN IMMUNE AND NEUROLOGICAL SIGNALING PATHWAYS}

\section{The PI3K-Akt-mTOR pathway}

In the past few decades, gene polymorphism and gene expression studies have revealed differences in ASD that seem to converge within common signaling pathways that are necessary for proper development and function of both the nervous system and the immune system. One such pathway is the mTOR pathway. ${ }^{76}$ Single-gene mutations that affect the mTOR pathway have been implicated in several monogenic disorders with a high rate of ASD (Table 5). Furthermore, a number of other genetic mutations that are linked to or feed into this pathway have been found in genome-wide association and copy number variation studies in ASD. ${ }^{80}$ Given the central role of this pathway, it is possible that many other rare gene variants could also exist that affect signaling through these pathways. Although these genetic differences are associated with a common pathway, they may exert an effect at different points and thus alter function and development in varied ways that could manifest as different endophenotypes within ASD.

Strikingly, many of the immune alterations seen in ASD could result from dysregulation of the mTOR pathway (FIG. 1). One of the earliest immune observations seen in ASD was reduced response to recall antigens. ${ }^{81}$ Other investigators have seen similar results in response to T-cell mitogens. ${ }^{82,83}$ As a central regulator of cell growth and metabolism, the mTOR pathway is intrinsically involved in both T-cell activation and anergy (i.e., a state of unresponsiveness), ${ }^{84}$ and hence dysfunction in this pathway could result in the T-cell abnormalities previously seen in ASD. In addition, cell survival is heavily regulated by the mTOR pathway. ${ }^{85}$ Dysregulated apoptosis in immune cells ${ }^{86}$ and neuronal cells ${ }^{87}$ has been described in ASD, which suggests that mechanisms controlling cell survival are altered. PTEN is a major upstream regulator in the mTOR pathway, and mutations in this protein are associated with higher rates of ASD. ${ }^{46}$

In an animal model with PTEN-deficient cells, Foxp3, a putative controller for the generation of regulatory T-cells, was found to be downregulated, ${ }^{88}$ leading to decreased number of cells that suppress immune responses and thus favoring immune dysfunction, activa-

Table 5. Monogenic Forms of ASD That Affect the mTOR Pathway

\begin{tabular}{llcll}
\hline \multicolumn{1}{c}{ Disorder } & Gene & Rate of ASD, $\%$ & \multicolumn{1}{c}{ Gene Function } & \multicolumn{1}{c}{ Reference } \\
\hline Fragile X syndrome & FMR1 & $30-60$ & Translational repressor & Clifford et al. $^{77}(2007)$ \\
Tuberous sclerosis complex & TCS1/2 & $25-50$ & mToR repressor & Wiznitzer $^{78}(2004)$ \\
PTEN hamartoma tumor syndrome & PTEN & no data & Inhibitor of PI3K & Herman et al. $^{46}(2007)$ \\
Neurofibromatosis type 1 & NF1 & 4 & Ras GAP & Williams and Hersh $^{79}(1998)$ \\
\hline
\end{tabular}




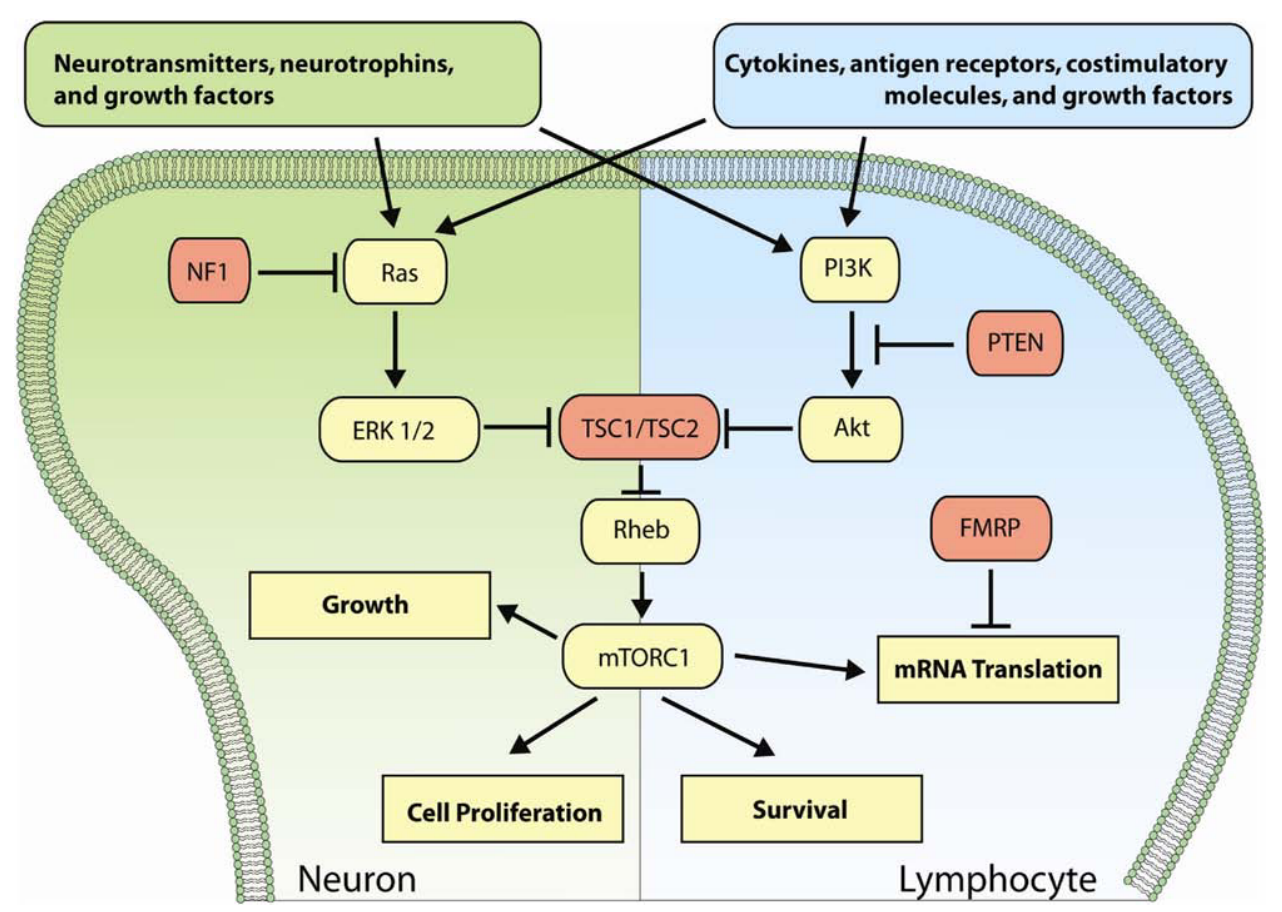

FIG. 1. mTOR signaling pathway in neurons and lymphocytes. Boxes shaded red indicate molecules known to be mutated in monogenic forms of autistic spectrum disorders.

tion, or both. A lack of immune regulation has been observed in ASD, as evinced by decreased plasma TGF $\beta 1$ and decreased IL-10 producing T-cells. ${ }^{51,52,56}$ Expression of FOXP3 has not yet been tested in ASD, but would be in line with mTOR dysregulation. ${ }^{89}$

In addition to abnormalities in the adaptive immune system in children with ASD, a number of differences have been noted in the innate immune system. Most relevant of these is the increase in proinflammatory cytokines, and the downregulation of IL- $10,{ }^{51,55,90}$ findings that correspond to the function of monocytes where mTOR is inhibited. ${ }^{91}$

\section{Neurotransmitters}

Similar to the immunological findings, neuropathological findings in ASD are numerous and varied (see review by Pardo and Eberhart ${ }^{92}$ ). Several studies have found increased brain size, brain structure differences, and reduced numbers of neurons in children with ASD, compared with control subjects. ${ }^{93-95}$ Although no direct cause of these abnormalities is known, it has been suggested that a dysregulation in neurotransmission could result in altered development. Differences in neurotransmitters (including serotonin and GABA) and in glutamate signaling pathways have been demonstrated in ASD (see review by Lam et al. ${ }^{96}$ ).

A considerable body of research has addressed the role of the serotonin system in ASD, including increased peripheral blood platelet serotonin levels in ASD. ${ }^{97,98}$ Serotonin has wide-ranging effects on physiological processes in the nervous, GI, and immune systems. Anti- bodies directed against serotonin receptors have also been reported in ASD, ${ }^{62,99}$ suggesting that the availability of serotonin may be different in ASD. Depletion of tryptophan, the precursor to serotonin, has been linked to increases in behaviors associated with ASD. ${ }^{100}$ The enzymes responsible for this conversion are under the control of cytokines such as IFN $\gamma$ and IL-1. ${ }^{101,102}$ Thus, increased tryptophan degradation as a result of aberrant immune activation could affect serotonin levels and thus affect behavior.

In the CNS, glutamate is the major excitatory neurotransmitter and GABA is the major inhibitory neurotransmitter. Receptors for glutamate and GABA are present in lymphocytes, and both neurotransmitters have been shown to exert modulatory effects on the immune response. ${ }^{103-105}$ Glutamate receptors are differentially expressed in activated versus naïve T-cells, and are believed to contribute to T-cell development and regulation. ${ }^{106}$ In addition, glutamate can augment the production of cytokines by lymphocytes, as well as their migratory ability. ${ }^{107,108}$

GABA receptors appear to have an inhibitory function on immune responses in a subset of lymphocytes, ${ }^{109}$ but may also increase pathogen clearance by macrophages. ${ }^{110}$ Receptors for glutamate and GABA can act as targets for autoantibodies, resulting in symptoms associated with those often seen in ASD. For example, antibodies against glutamate receptors have been implicated in childhood seizure disorders, ${ }^{112}$ a common comorbidity of ASD, ${ }^{111,112}$ whereas antibodies against GABA recep- 
tors are associated with motor disorders, ${ }^{113}$ which are widely reported in ASD. ${ }^{114}$ Although antibodies for either receptor family have not been detected in ASD, numerous unknown targets for autoantibodies exist, and it is possible that these could include subunits of the GABA or glutamate receptors. Dysregulation of neurotransmitter systems could further drive aberrant immune responses in ASD and could thus point to possible targets for therapeutic intervention.

\section{IMMUNE THERAPIES}

Immune-based therapies have been suggested for ASD, but few have been tested. The suggested therapies are based largely on anecdotal observations, and very few rigorous placebo-controlled studies have been reported. It is estimated, however, that $50-70 \%$ of children with ASD undergo complementary and alternative medicinal therapies to treat their symptoms. ${ }^{115-118}$ These therapies include the use of probiotics, anti-infectives, and dietary augmentation. ${ }^{119}$ The clinical trials aimed at testing therapies that modulate the immune response in children with ASD often involve very few patients and lack appropriate controls.

Studies have addressed the use of steroids, ${ }^{120-124}$ intravenous immune $\mathrm{Ig},{ }^{125-127}$ antibiotics, ${ }^{128}$ and vitamin D. ${ }^{129}$ The findings vary, however, and often are contradictory. The modest but positive findings of improved behaviors in some studies suggest that a subgroup of individuals with ASD could benefit from immune-based therapies. Given the limitations of these studies, however, it is impossible to ascertain whether the benefits are real or merely placebo effects, as has been reported in other therapies for ASD. ${ }^{130}$ Better patient selection with biological as well as behavioral assessment in the context of placebo-controlled studies that are conducted over sufficient periods of time are needed.

\section{CONCLUSION AND FUTURE DIRECTIONS}

Immune abnormalities have been observed in ASD for many years. Although low patient numbers or poor choice of control subjects limit many of these observations, the general theme of immune dysfunction in ASD has been raised. Future work in the field will need to determine the extent of immune abnormalities in the broader ASD phenotype and whether immune dysfunction contributes to the etiology. Observations of autoantibodies directed against brain or other CNS components in children with ASD may help both in the diagnosis of subgroups of ASD and in identifying potential targets for therapies.

As understanding of ASD progresses, it appears more and more likely that there is no single cause of the disorder, whether on a genetic or an environmental level.
Insights into the common signaling pathway disruptions seen in monogenic forms of ASD, as well as the role these pathways play in regulating the immune system, may provide clues to better understanding the biology of ASD, and a better understanding of the immune dysfunction seen in ASD would undoubtedly provide direction for investigating therapeutic strategies.

\section{REFERENCES}

1. Money J, Bobrow NA, Clarke FC. Autism and autoimmune disease: a family study. J Autism Child Schizophr 1971;1:146-160.

2. Atladóttir HO, Pedersen MG, Thorsen P, et al. Association of family history of autoimmune diseases and autism spectrum disorders. Pediatrics 2009;124:687-694.

3. Croen LA, Grether JK, Yoshida CK, Odouli R, Van de Water J. Maternal autoimmune diseases, asthma and allergies, and childhood autism spectrum disorders: a case-control study. Arch Pediatr Adolesc Med 2005;159:151-157.

4. Cooper GS, Bynum ML, Somers EC. Recent insights in the epidemiology of autoimmune diseases: improved prevalence estimates and understanding of clustering of diseases. J Autoimmun 2009;33:197-207.

5. Comi AM, Zimmerman AW, Frye VH, Law PA, Peeden JN. Familial clustering of autoimmune disorders and evaluation of medical risk factors in autism. J Child Neurol 1999;14:388-394.

6. Sweeten TL, Bowyer SL, Posey DJ, Halberstadt GM, McDougle CJ. Increased prevalence of familial autoimmunity in probands with pervasive developmental disorders. Pediatrics 2003;112: e420.

7. Micali N, Chakrabarti S, Fombonne E. The broad autism phenotype: findings from an epidemiological survey. Autism 2004;8: 21-37.

8. Molloy CA, Morrow AL, Meinzen-Derr J, et al. Familial autoimmune thyroid disease as a risk factor for regression in children with autism spectrum disorder: a CPEA Study. J Autism Dev Disord 2006;36:317-324.

9. Mouridsen SE, Rich B, Isager T, Nedergaard NJ. Autoimmune diseases in parents of children with infantile autism: a casecontrol study. Dev Med Child Neurol 2007;49:429-432.

10. Valicenti-McDermott MD, McVicar K, Cohen HJ, Wershil BK, Shinnar S. Gastrointestinal symptoms in children with an autism spectrum disorder and language regression. Pediatr Neurol 2008; 39:392-398.

11. Tincani A, Rebaioli CB, Frassi M, et al.; Pregnancy Study Group of Italian Society of Rheumatology. Pregnancy and autoimmunity: maternal treatment and maternal disease influence on pregnancy outcome. Autoimmun Rev 2005;4:423-428.

12. Croen LA, Braunschweig D, Haapanen L, et al. Maternal midpregnancy autoantibodies to fetal brain protein: the early markers for autism study. Biol Psychiatry 2008;64:583-588.

13. Warren RP, Cole P, Odell JD, et al. Detection of maternal antibodies in infantile autism. J Am Acad Child Adolesc Psychiatry 1990;29:873-877.

14. Dalton P, Deacon R, Blamire A, et al. Maternal neuronal antibodies associated with autism and a language disorder. Ann Neurol 2003;53:533-537.

15. Zimmerman AW, Connors SL, Matteson KJ, et al. Maternal antibrain antibodies in autism. Brain Behav Immun 2007;21:351357.

16. Braunschweig D, Ashwood P, Krakowiak P, et al. Autism: maternally derived antibodies specific for fetal brain proteins. Neurotoxicology 2008;29:226-231.

17. Singer HS, Morris CM, Gause CD, Gillin PK, Crawford S, Zimmerman AW. Antibodies against fetal brain in sera of mothers with autistic children. J Neuroimmunol 2008;194:165-172.

18. Martin LA, Ashwood P, Braunschweig D, Cabanlit M, Van de Water J, Amaral DG. Stereotypies and hyperactivity in rhesus monkeys exposed to IgG from mothers of children with autism. Brain Behav Immun 2008;22:806-816. 
19. Singer HS, Morris C, Gause C, Pollard M, Zimmerman AW, Pletnikov M. Prenatal exposure to antibodies from mothers of children with autism produces neurobehavioral alterations: a pregnant dam mouse model. J Neuroimmunol 2009;211:39-48.

20. Silva SC, Correia C, Fesel C, et al. Autoantibody repertoires to brain tissue in autism nuclear families. J Neuroimmunol 2004; 152:176-182.

21. McAllister DL, Kaplan BJ, Edworthy SM, et al. The influence of systemic lupus erythematosus on fetal development: cognitive, behavioral, and health trends. J Int Neuropsychol Soc 1997;3: 370-376.

22. Neri F, Chimini L, Bonomi F, et al. Neuropsychological development of children born to patients with systemic lupus erythematosus. Lupus 2004;13:805-811.

23. Tincani A, Danieli E, Nuzzo M, et al.; Pregancy Study Group of Italian Society of Rheumatology. Impact of in utero environment on the offspring of lupus patients. Lupus 2006;15:801-807.

24. Lee LA. The clinical spectrum of neonatal lupus. Arch Dermatol Res 2009;301:107-110.

25. Lee JY, Huerta PT, Zhang J, et al. Neurotoxic autoantibodies mediate congenital cortical impairment of offspring in maternal lupus. Nat Med 2009;15:91-96.

26. Klauck SM, Poustka A. Animal models of autism. Drug Discov Today Dis Models 2006;3:313-318.

27. Enstrom AM, Van de Water JA, Ashwood P. Autoimmunity in autism. Curr Opin Investig Drugs 2009;10:463-473.

28. Fernando MM, Stevens CR, Walsh EC, et al. Defining the role of the MHC in autoimmunity: a review and pooled analysis. PLoS Genet 2008;4:e1000024.

29. Stubbs EG, Magenis RE. HLA and autism. J Autism Dev Disord 1980;10:15-19.

30. Stubbs EG, Ritvo ER, Mason-Brothers A. Autism and shared parental HLA antigens. J Am Acad Child Psychiatry 1985;24: 182-185.

31. Spence MA, Ritvo ER, Marazita ML, Funderburk SJ, Sparkes RS, Freeman BJ. Gene mapping studies with the syndrome of autism. Behav Genet 1985;15:1-13.

32. Warren RP, Singh VK, Cole P, et al. Possible association of the extended MHC haplotype B44-SC30-DR4 with autism. Immunogenetics 1992;36:203-207.

33. Daniels WW, Warren RP, Odell JD, et al. Increased frequency of the extended or ancestral haplotype B44-SC30-DR4 in autism. Neuropsychobiology 1995;32:120-123.

34. Warren RP, Singh VK, Averett RE, et al. Immunogenetic studies in autism and related disorders. Mol Chem Neuropathol 1996;28: 77-81.

35. Rogers T, Kalaydjieva L, Hallmayer J, et al. Exclusion of linkage to the HLA region in ninety multiplex sibships with autism. J Autism Dev Disord 1999;29:195-201.

36. Torres AR, Maciulis A, Stubbs EG, Cutler A, Odell D. The transmission disequilibrium test suggests that HLA-DR4 and DR13 are linked to autism spectrum disorder. Hum Immunol 2002;63:311-316.

37. Lee LC, Zachary AA, Leffell MS, et al. HLA-DR4 in families with autism. Pediatr Neurol 2006;35:303-307.

38. Guerini FR, Bolognesi E, Manca S, et al. Family-based transmission analysis of HLA genetic markers in Sardinian children with autistic spectrum disorders. Hum Immunol 2009;70:184-190.

39. Johnson WG, Buyske S, Mars AE, et al. HLA-DR4 as a risk allele for autism acting in mothers of probands possibly during pregnancy. Arch Pediatr Adolesc Med 2009;163:542-546.

40. Warren RP, Burger RA, Odell D, Torres AR, Warren WL. Decreased plasma concentrations of the $\mathrm{C} 4 \mathrm{~B}$ complement protein in autism. Arch Pediatr Adolesc Med 1994;148:180-183.

41. Warren RP, Yonk J, Burger RW, Odell D, Warren WL. DRpositive $\mathrm{T}$ cells in autism: association with decreased plasma levels of the complement C4B protein. Neuropsychobiology 1995;31:53-57.

42. Odell D, Maciulis A, Cutler A, et al. Confirmation of the association of the C4B null allele in autism. Hum Immunol 2005;66: $140-145$.

43. Grigorenko EL, Han SS, Yrigollen CM, et al. Macrophage mi- gration inhibitory factor and autism spectrum disorders. Pediatrics 2008; 122:e438-e445.

44. Correll PH, Morrison AC, Lutz MA. Receptor tyrosine kinases and the regulation of macrophage activation. J Leukoc Biol 2004; 75:731-737.

45. Lintas C, Sacco R, Garbett K, et al. Involvement of the PRKCBI gene in autistic disorder: significant genetic association and reduced neocortical gene expression. Mol Psychiatry 2009;14:705-718.

46. Herman GE, Butter E, Enrile B, Pastore M, Prior TW, Sommer A. Increasing knowledge of PTEN germline mutations: two additional patients with autism and macrocephaly. Am J Med Genet A 2007;143:589-593.

47. Serajee FJ, Zhong H, Mahbubul Huq AH. Association of Reelin gene polymorphisms with autism. Genomics 2006;87:75-83.

48. Skaar DA, Shao Y, Haines JL, et al. Analysis of the RELN gene as a genetic risk factor for autism. Mol Psychiatry 2005;10:563-571.

49. Zhang H, Liu X, Zhang C, et al. Reelin gene alleles and susceptibility to autism spectrum disorders. Mol Psychiatry 2002;7: 1012-1017.

50. Vargas DL, Nascimbene C, Krishnan C, Zimmerman AW, Pardo CA. Neuroglial activation and neuroinflammation in the brain of patients with autism [Erratum in: Ann Neurol 2005;57:304]. Ann Neurol 2005;57:67-81.

51. Ashwood P, Anthony A, Torrente F, Wakefield AJ. Spontaneous mucosal lymphocyte cytokine profiles in children with autism and gastrointestinal symptoms: mucosal immune activation and reduced counter regulatory interleukin-10. J Clin Immunol 2004; 24:664-673.

52. Ashwood P, Wakefield AJ. Immune activation of peripheral blood and mucosal $\mathrm{CD}^{+}$lymphocyte cytokine profiles in children with autism and gastrointestinal symptoms. J Neuroimmunol 2006;173:126-134.

53. Singh VK, Warren RP, Odell JD, Cole P. Changes of soluble interleukin-2, interleukin-2 receptor, T8 antigen, and interleukin-1 in the serum of autistic children. Clin Immunol Immunopathol 1991;61:448-455.

54. Singh VK. Plasma increase of interleukin-12 and interferongamma. Pathological significance in autism. J Neuroimmunol 1996;66:143-145.

55. Jyonouchi H, Sun S, Le H. Proinflammatory and regulatory cytokine production associated with innate and adaptive immune responses in children with autism spectrum disorders and developmental regression. J Neuroimmunol 2001;120:170-179.

56. Ashwood P, Enstrom A, Krakowiak P, et al. Decreased transforming growth factor beta1 in autism: a potential link between immune dysregulation and impairment in clinical behavioral outcomes. J Neuroimmunol 2008;204:149-153.

57. Jyonouchi H, Sun S, Itokazu N. Innate immunity associated with inflammatory responses and cytokine production against common dietary proteins in patients with autism spectrum disorder. Neuropsychobiology 2002;46:76-84.

58. Ashwood P, Anthony A, Pellicer AA, Torrente F, Walker-Smith JA, Wakefield AJ. Intestinal lymphocyte populations in children with regressive autism: evidence for extensive mucosal immunopathology. J Clin Immunol 2003;23:504-517.

59. Horvath K, Perman JA. Autism and gastrointestinal symptoms. Curr Gastroenterol Rep 2002;4:251-258.

60. Genuis SJ, Bouchard TP. Celiac disease presenting as autism. J Child Neurol 2010;25:114-119.

61. Wills S, Cabanlit M, Bennett J, Ashwood P, Amaral D, Van de Water J. Autoantibodies in autism spectrum disorders (ASD). Ann N Y Acad Sci 2007;1107:79-91.

62. Todd RD, Ciaranello RD. Demonstration of inter- and intraspecies differences in serotonin binding sites by antibodies from an autistic child. Proc Natl Acad Sci U S A 1985;82:612-616.

63. Singh VK, Warren RP, Odell JD, Warren WL, Cole P. Antibodies to myelin basic protein in children with autistic behavior. Brain Behav Immun 1993;7:97-103.

64. Singh VK, Warren R, Averett R, Ghaziuddin M. Circulating autoantibodies to neuronal and glial filament proteins in autism. Pediatr Neurol 1997;17:88-90.

65. Singh VK, Lin SX, Yang VC. Serological association of measles 
virus and human herpesvirus- 6 with brain autoantibodies in autism. Clin Immunol Immunopathol 1998;89:105-108.

66. Evers M, Cunningham-Rundles C, Hollander E. Heat shock protein 90 antibodies in autism. Mol Psychiatry 2002;7 Suppl 2:S26S28.

67. Vojdani A, O’Bryan T, Green JA, et al. Immune response to dietary proteins, gliadin and cerebellar peptides in children with autism. Nutr Neurosci 2004;7:151-161.

68. Singh VK, Rivas WH. Prevalence of serum antibodies to caudate nucleus in autistic children. Neurosci Lett 2004;355:53-56.

69. Singh VK, Rivas WH. Detection of antinuclear and antilaminin antibodies in autistic children who received thimerosal-containing vaccines. J Biomed Sci 2004;11:607-610.

70. Connolly AM, Chez M, Streif EM, et al. Brain-derived neurotrophic factor and autoantibodies to neural antigens in sera of children with autistic spectrum disorders, Landau-Kleffner syndrome, and epilepsy. Biol Psychiatry 2006;59:354-363.

71. Singer HS, Morris CM, Williams PN, Yoon DY, Hong JJ, Zimmerman AW. Antibrain antibodies in children with autism and their unaffected siblings. J Neuroimmunol 2006;178:149-155.

72. Libbey JE, Coon HH, Kirkman NJ, et al. Are there enhanced MBP autoantibodies in autism? J Autism Dev Disord 2008;38: 324-332.

73. Kirkman NJ, Libbey JE, Sweeten TL, et al. How relevant are GFAP autoantibodies in autism and Tourette Syndrome? J Autism Dev Disord 2008;38:333-341.

74. Wills S, Cabanlit M, Bennett J, Ashwood P, Amaral DG, Van de Water J. Detection of autoantibodies to neural cells of the cerebellum in the plasma of subjects with autism spectrum disorders. Brain Behav Immun 2009;23:64-74.

75. Torrente F, Ashwood P, Day R, et al. Small intestinal enteropathy with epithelial $\operatorname{IgG}$ and complement deposition in children with regressive autism. Mol Psychiatry 2002;7:375-382, 334.

76. Wullschleger S, Loewith R, Hall MN. TOR signaling in growth and metabolism. Cell 2006;124:471-484.

77. Clifford S, Dissanayake C, Bui QM, Huggins R, Taylor AK, Loesch DZ. Autism spectrum phenotype in males and females with fragile $\mathrm{X}$ full mutation and premutation. J Autism Dev Disord 2007;37:738-747.

78. Wiznitzer M. Autism and tuberous sclerosis. J Child Neurol 2004;19:675-679.

79. Williams PG, Hersh JH. Brief report: the association of neurofibromatosis type 1 and autism. J Autism Dev Disord 1998;28:567571.

80. Cuscó I, Medrano A, Gener B, et al. Autism-specific copy number variants further implicate the phosphatidylinositol signaling pathway and the glutamatergic synapse in the etiology of the disorder. Hum Mol Genet 2009;18:1795-1804.

81. Stubbs EG. Autistic children exhibit undetectable hemagglutination-inhibition antibody titers despite previous rubella vaccination. J Autism Child Schizophr 1976;6:269-274.

82. Warren RP, Margaretten NC, Pace NC, Foster A. Immune abnormalities in patients with autism. J Autism Dev Disord 1986; 16:189-197.

83. Murch SH, Fertleman CR, Rodrigues C, et al. Autoimmune enteropathy with distinct mucosal features in T-cell activation deficiency: the contribution of T cells to the mucosal lesion. J Pediatr Gastroenterol Nutr 1999;28:393-399.

84. Mondino A, Mueller DL. mTOR at the crossroads of T cell proliferation and tolerance. Semin Immunol 2007;19:162-172.

85. Castedo M, Ferri KF, Kroemer G. Mammalian target of rapamycin (mTOR): pro- and anti-apoptotic. Cell Death Differ 2002;9: 99-100.

86. Engstrom HA, Ohlson S, Stubbs EG, et al. Decreased expression of CD95 (FAS/APO-1) on CD4 ${ }^{+}$T-lymphocytes from participants with autism. J Dev Phys Disabil 2003;15:155-163.

87. Fatemi SH, Stary JM, Halt AR, Realmuto GR. Dysregulation of reelin and $\mathrm{Bcl}-2$ proteins in autistic cerebellum. J Autism Dev Disord 2001;31:529-535.

88. Sauer S, Bruno L, Hertweck A, et al. T cell receptor signaling controls Foxp3 expression via PI3K, Akt, and mTOR. Proc Natl Acad Sci U S A 2008;105:7797-7802.
89. Wu T, Mohan C. The AKT axis as a therapeutic target in autoimmune diseases. Endocr Metab Immune Disord Drug Targets 2009;9:145-150.

90. Jyonouchi H, Geng L, Ruby A, Zimmerman-Bier B. Dysregulated innate immune responses in young children with autism spectrum disorders: their relationship to gastrointestinal symptoms and dietary intervention. Neuropsychobiology 2005;51:77-85.

91. Weichhart T, Costantino G, Poglitsch M, et al. The TSC-mTOR signaling pathway regulates the innate inflammatory response. Immunity 2008;29:565-577.

92. Pardo CA, Eberhart CG. The neurobiology of autism. Brain Pathol 2007;17:434-447.

93. Volkmar FR, Pauls D. Autism [Erratum in: Lancet 2004;363: 250]. Lancet 2003;362:1133-1141.

94. Kemper TL, Bauman ML. Neuropathology of infantile autism. Mol Psychiatry 2002;7 Suppl 2:S12-S13.

95. Courchesne E, Pierce K. Brain overgrowth in autism during a critical time in development: implications for frontal pyramidal neuron and interneuron development and connectivity. Int J Dev Neurosci 2005;23:153-170.

96. Lam KS, Aman MG, Arnold LE. Neurochemical correlates of autistic disorder: a review of the literature. Res Dev Disabil 2006;27:254-289.

97. Anderson GM, Horne WC, Chatterjee D, Cohen DJ. The hyperserotonemia of autism. Ann N Y Acad Sci 1990;600:331-340; discussion 341-332.

98. Rolf LH, Haarmann FY, Grotemeyer KH, Kehrer H. Serotonin and amino acid content in platelets of autistic children. Acta Psychiatr Scand 1993;87:312-316.

99. Singh VK, Singh EA, Warren RP. Hyperserotoninemia and serotonin receptor antibodies in children with autism but not mental retardation. Biol Psychiatry 1997;41:753-755.

100. McDougle CJ, Naylor ST, Cohen DJ, Aghajanian GK, Heninger GR, Price LH. Effects of tryptophan depletion in drug-free adults with autistic disorder. Arch Gen Psychiatry 1996;53:993-1000.

101. Dunn AJ, Wang J, Ando T. Effects of cytokines on cerebral neurotransmission: comparison with the effects of stress. Adv Exp Med Biol 1999;461:117-127.

102. Wirleitner B, Neurauter G, Schröcksnadel K, Frick B, Fuchs D. Interferon- $\gamma$-induced conversion of tryptophan: immunologic and neuropsychiatric aspects. Curr Med Chem 2003;10:1581-1591.

103. Bjurstöm H, Wang J, Ericsson I, et al. GABA, a natural immunomodulator of T lymphocytes. J Neuroimmunol 2008;205:4450.

104. Levite M. Neurotransmitters activate T-cells and elicit crucial functions via neurotransmitter receptors. Curr Opin Pharmacol 2008;8:460-471.

105. Pacheco R, Gallart T, Lluis C, Franco R. Role of glutamate on T-cell mediated immunity. J Neuroimmunol 2007;185:9-19.

106. Pacheco R, Ciruela F, Casadó V, et al. Group I metabotropic glutamate receptors mediate a dual role of glutamate in $\mathrm{T}$ cell activation. J Biol Chem 2004;279:33352-33358.

107. Sarchielli P, Di Filippo M, Candeliere A, et al. Expression of ionotropic glutamate receptor GLUR3 and effects of glutamate on MBP- and MOG-specific lymphocyte activation and chemotactic migration in multiple sclerosis patients. J Neuroimmunol 2007; 188:146-158.

108. Pacheco R, Oliva H, Martinez-Navio JM, et al. Glutamate released by dendritic cells as a novel modulator of T cell activation. J Immunol 2006;177:6695-6704.

109. Alam S, Laughton DL, Walding A, Wolstenholme AJ. Human peripheral blood mononuclear cells express $\mathrm{GABA}_{\mathrm{A}}$ receptor subunits. Mol Immunol 2006;43:1432-1442.

110. Lubick K, Radke M, Jutila M. Securinine, a $\mathrm{GABA}_{\mathrm{A}}$ receptor antagonist, enhances macrophage clearance of phase II $C$. burnetii: comparison with TLR agonists [Erratum in: J Leukoc Biol 2008;83:1068]. J Leukoc Biol 2007;82:1062-1069.

111. Levite M, Ganor Y. Autoantibodies to glutamate receptors can damage the brain in epilepsy, systemic lupus erythematosus and encephalitis. Expert Rev Neurother 2008;8:1141-1160.

112. Volkmar FR, Nelson DS. Seizure disorders in autism. J Am Acad Child Adolesc Psychiatry 1990;29:127-129. 
113. Raju R, Rakocevic G, Chen Z, et al. Autoimmunity to GABA $\mathrm{A}^{-}$ receptor-associated protein in stiff-person syndrome. Brain 2006; 129:3270-3276.

114. Ghaziuddin M, Butler E. Clumsiness in autism and Asperger syndrome: a further report. J Intellect Disabil Res 1998;42 (Pt 1): 43-48.

115. Levy SE, Mandell DS, Merhar S, Ittenbach RF, Pinto-Martin JA. Use of complementary and alternative medicine among children recently diagnosed with autistic spectrum disorder. J Dev Behav Pediatr 2003;24:418-423.

116. Hanson E, Kalish L, Bunce E, et al. Use of complementary and alternative medicine among children diagnosed with autism spectrum disorder. J Autism Dev Disord 2007;37:628-636.

117. Harrington JW, Rosen L, Garnecho A, Patrick PA. Parental perceptions and use of complementary and alternative medicine practices for children with autistic spectrum disorders in private practice. J Dev Behav Pediatr 2006;27:S156-S161.

118. Wong HH, Smith RG. Patterns of complementary and alternative medical therapy use in children diagnosed with autism spectrum disorders. J Autism Dev Disord 2006;36:901-909.

119. Golnik A, Ireland M. complementary alternative medicine for children with autism: a physician survey. J Autism Dev Disord 2009;39:996-1005.

120. Geier MR, Geier DA. The potential importance of steroids in the treatment of autistic spectrum disorders and other disorders involving mercury toxicity. Med Hypotheses 2005;64:946-954.

121. Buitelaar JK, van Engeland H, van Ree JM, de Wied D. Behav- ioral effects of Org 2766, a synthetic analog of the adrenocorticotrophic hormone (4-9), in 14 outpatient autistic children. J Autism Dev Disord 1990;20:467-478.

122. Bradstreet JJ, Smith S, Granpeesheh D, El-Dahr JM, Rossignol D. Spironolactone might be a desirable immunologic and hormonal intervention in autism spectrum disorders. Med Hypotheses 2007; 68:979-987.

123. Matarazzo EB. Treatment of late onset autism as a consequence of probable autoimmune processes related to chronic bacterial infection. World J Biol Psychiatry 2002;3:162-166.

124. Shenoy S, Arnold S, Chatila T. Response to steroid therapy in autism secondary to autoimmune lymphoproliferative syndrome. J Pediatr 2000;136:682-687.

125. Dalakas MC. Intravenous immune globulin therapy for neurologic diseases. Ann Intern Med 1997;126:721-730.

126. Plioplys AV. Intravenous immunoglobulin treatment of children with autism. J Child Neurol 1998;13:79-82.

127. Gupta S. Treatment of children with autism with intravenous immunoglobulin. J Child Neurol 1999;14:203-205.

128. Sandler RH, Finegold SM, Bolte ER, et al. Short-term benefit from oral vancomycin treatment of regressive-onset autism. J Child Neurol 2000;15:429-435.

129. Cannell JJ. Autism and vitamin D. Med Hypotheses 2008;70: $750-759$.

130. Sandler A. Placebo effects in developmental disabilities: implications for research and practice. Ment Retard Dev Disabil Res Rev 2005;11:164-170. 